\title{
RANCANG BANGUN POMPA HIDRAM UNTUK MASYARAKAT PEDESAAN
}

\author{
Oleh : \\ Arie Herlambang dan Heru Dwi Wahjono \\ Peneliti Pada Pusat Teknologi Lingkungan, TPSA - BPPT
}

\begin{abstract}
Environmental contamination and global climate change cause degradation of fresh water in the whole world. Increasing of oil price also insist the water treatment operational cost rise, especially for pumping and water lifting from the low land areas to up land. One of alternatif solution to reduce operational cost is using Hydraulic ram pumps (hydram pump). Hydram pump are water-lifting devices that are powered by filling water. Such pumps work by using the energy of water falling a small height to lift a small part of that amount of water to a much greater height. In this way, water from a spring or stream in a valley can be pumped to a village or irrigation scheme on the hillside. The main and unique advantage of hydram pumps is that with a continuous flow of water, a hydram pump operates automatically and continuously with no other external energy source - be it electricity or hydrocarbon fuel. It uses a renewable energy source (stream of water) mid hence ensures low running cost. Minimum up lifting vertical power of pump is twice than vertical distance of water down and maximum up lifting vertical power is twenty times than vertical distance of water down. If there are air captured in distribution pipe, it will need release valve. In this paper, different aspect of designing a hydraulic-rain pump system is discussed. Application and limitation of hydram pump is presented. It imparts absolutely no harm to the environment Hydraulic ram pumps are simple, reliable and require minimal maintenance. All these advantages make hydram pumps suitable to rural community water supply and mud backyard irrigation in developing countries.
\end{abstract}

Kata Kunci : Air bersih pedesaan, pompa hidram, pengelolaan air bersih.

\section{PENDAHULUAN}

Air merupakan sarana yang penting dalam kehidupan manusia dan hewan maupun tumbuh-tumbuhan. Di samping itu air juga merupakan sumber tenaga yang disediakan oleh alam yang dapat digunakan sebagai pembangkit tenaga mekanis. Kenyataan telah menunjukkan bahwa ada banyak daerah di pedesaan yang mengalami kesulitan penyediaan air, baik untuk kebutuhan rumah tangga maupun untuk kegiatan pertanian. Sebenarnya untuk mengatasi keadaan tersebut, pemakaian pompa air, baik yang digerakkan oleh tenaga listrik maupun oleh tenaga diesel telah lama dikenal oleh masyarakat desa, tetapi pada kenyataannya masih banyak masyarakat pedesaan yang belum memilikinya. Hal ini disebabkan karena kemampuan daya beli masyarakat desa masih terbatas, dan pada penggunaan suatu unit pompa-pompa bermesin dibutuhkan tenaga operator yang terampil. Di samping itu, alat tersebut harus mempunyai kualitas yang baik dan tersedianya suku cadang yang mudah diperoleh di pasaran bebas.

Untuk dapat menanggulangi masalah penyediaan air baik untuk kehidupan maupun untuk kegiatan pertanian, peternakan dan perikanan khususnya di daerah pedesaan, maka penggunaan pompa Hidraulik ram (hidram) yang sangat sederhana, baik dalam pembuatannya dan juga dalam pemeliharaannya, mempunyai prospek yang sangat baik.

Pompa hidram sudah digunakan sejak dua abad lalu dibanyak tempat di dunia. Pompa hidram pertama dibuat oleh John Whitehurst pada tahun 1775. Kesederhanaan dan kemudahan dalam pemeliharaan membuat pompa hidram sukses secara komersial, terutama di Eropa sebelum digunakan secara luas tenaga listrik dan mesin pompa. Di Amerika, pompa hidram terbesar pernah dibuat dengan diameter $300 \mathrm{~mm}$ mampu memompa 1700 liter/menit sampai ketinggian 43 meter. Namun karena perkembangan teknologi yang pesat dan meningkatnya ketergantungan pada bahan baker fosil, maka pompa hidram diabaikan. Akhir akhir ini dengan meningkatnya perhatian pada peralatan-peralatan untuk energi terbarukan dan kesadaran kebutuhan teknologi di negara berkembang, pompa hidram mulai dipakai kembali.

Pompa hidram bekerja tanpa menggunakan bahan bakar atau tambahan energi dari luar. Pompa ini memanfaatkan tenaga aliran air yang jatuh dari tempat suatu sumber ar dan sebagian dari air itu dipompakan ke tempat yang lebih tinggi. Pada berbagai situasi, penggunaan pompa hidram memiliki banyak keuntungan dibandingkan 
penggunaan jenis pompa air lainnya, diantaranya, tidak membutuhkan bahan bakar atau tambahan tenaga dari sumber lain, tidak membutuhkan pelumasan, bentuknya sangat sederhana, dan biaya pembuatannya serta pemeliharaannya sangat murah dan tidak membutuhkan keterampilan teknik tinggi untuk membuatnya. Selain itu pompa ini mampu bekerja dua puluh empat jam per hari. Pompa hidram sangat tepat untuk daerah-daerah yang penduduknya mempunyai keterampilan teknis yang terbatas, karena pemeliharaan yang dibutuhkan sederhana.

\section{TUJUAN DAN SASARAN}

Kegiatan ini bertujuan untuk
menerapkan teknologi sederhana bagi
masyarakat pedesaan, khususnya yang
memiliki masalah penyediaan air bersih.
Sedangkan sasarannya adalah membantu
meningkatkan keterampilan masyarakat desa
dengan teknologi sederhana untuk mengatasi
permasalahan ketersediaan air bersih
khususnya bagi desa yang memiliki sumber air
yang berada di bawah dimana lokasi desa itu
berada.

\section{HIDRAM AUTOMATIK}

\subsection{Diskrpsi}

Hidraulik ram (hidram) merupakan suatu alat yang digunakan untuk menaikkan air dari tempat rendah ke tempat yang lebih tinggi secara automatik dengan energi yang berasal dari air itu sendiri (Gambar 1). Alat ini sederhana dan efektif digunakan pada kondisi yang sesuai dengan syarat-syarat yang diperlukan untuk operasinya. Dalam kerjanya alat ini, tekanan dinamik air yang ditimbulkan memungkinkan air mengalir dari tinggi vertikal (head) yang rendah, ke tempat yang lebih tinggi. Penggunaan hidram tidak terbatas hanya pada penyediaan air untuk kebutuhan rumah tangga, tapi juga dapat digunakan untuk memenuhi kebutuhan air untuk pertanian, peternakan dan perikanan darat. Di beberapa pedesaan di Jepang, alat ini telah banyak digunakan sebagai alat penyediaan air untuk kegiatan pertanian maupun untuk keperluan domestik.

Dalam operasinya, alat ini mempunyai keuntungan dibandingkan dengan jenis pompa lainnya, yaitu tidak membutuhkan sumber tenaga tambahan, biaya operasinya murah, tidak memerlukan pelumasan, hanya memiliki dua bagian yang bergerak sehingga memperkecil terjadinya keausan, perawatannya sederhana dan dapat bekerja dengan efisien pada kondisi yang sesuai serta dapat dibuat dengan peralatan bengkel yang sederhana.

Cara kerja hidram dan bagian-bagian utamanya terlihat pada Gambar 2 dan 3. Air mengalir dari suatu sumber atau sebuah tangki melalui pipa pemasukan dan keluar melalui katup limbah.

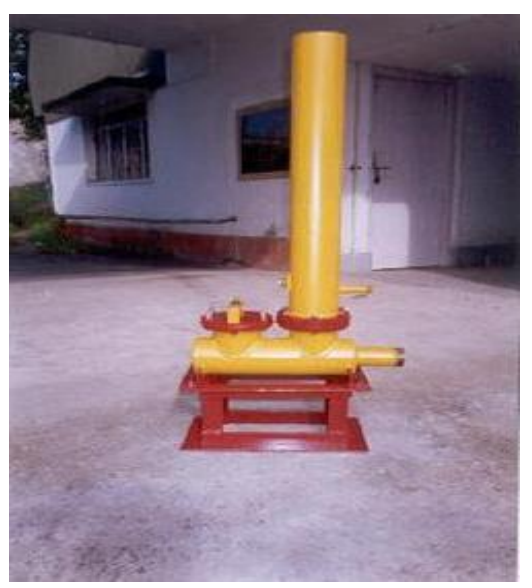

Gambar 1: Contoh Pompa hidram model no: hidram 2x1 / hidram 4x2 / hidram 6x3 esenco hidram, buatan india sertifikasi iso 9001 .

\subsection{Prinsip Kerja}

Prinsip kerja hidram automatik merupakan proses perubahan energi kenetis aliran air menjadi tekanan dinamik dan sebagai akibatnya menimbulkan efek palu air (water hammer) sehingga terjadi tekanan tinggi dalam pipa. Dengan mengusahakan supaya katup limbah (waste valve) dan katup air keluar (delivery valve) terbuka dan tertutup secara bergantian, maka tekanan dinamik diteruskan sehingga tekanan inersia yang terjadi dalam pipa pemasukan memaksa air naik ke pipa pengantar. Bagian-bagian utama yang menyusun alat ini terdiri dari pipa air masuk (drive pipe), pipa air keluar (delivery valve), katup udara (air valve) dan ruang udara (air chamber).

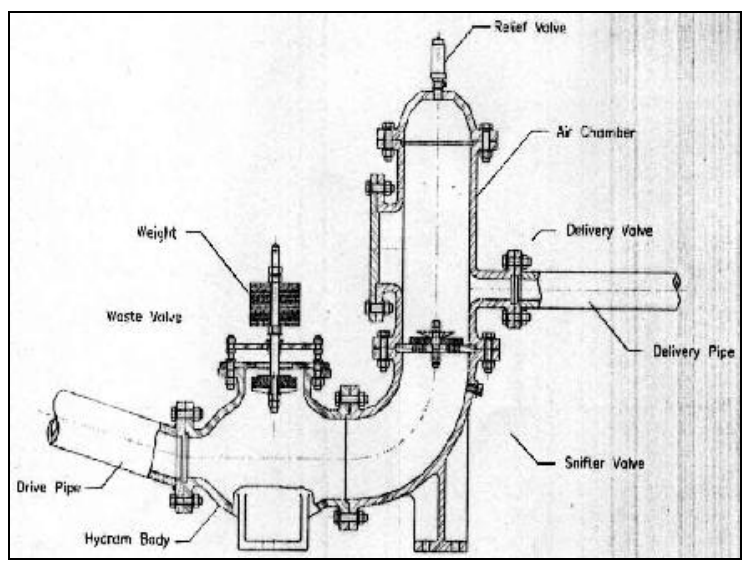

Gambar 2 : Penampang Samping Pompa Hidram 
Aliran air yang melalui katup limbah cukup cepat, maka tekanan dinamik yang merupakan gaya ke atas mendorong katup limbah sehingga tertutup secara tiba-tiba sambil menghentikan aliran air dalam pipa pemasukan. Aliran air yang terhenti mengakibatkan tekanan tinggi terjadi dalam ram, jika tekanan cukup besar akan mengatasi tekanan dalam ruang udara pada katup pengantar dengan demikian membiarkan air mengalir ke dalam ruang udara dan seterusnya ke tangki penampungan.

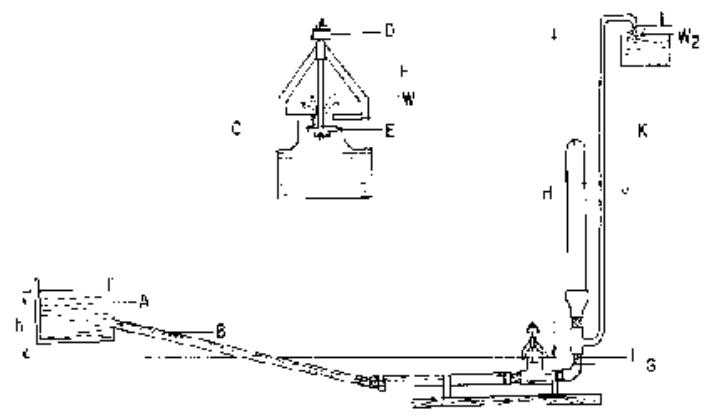

Keterangan :

A. Tangki Pemasukan

B. Pipa Pemasukan

C. Lubang Katup Limbah

D. Pemberat Katup Limbah

E. Katup Limbah

F. Tangkai Katup Limbah

G. Katup Udara

I. Katup Penghantar

J. Ruang Udara

K. Pipa Penghantar

L. Lubang pengeluaran pipa penghantar

$H$. Tinggi vertikal antara lubang katup limbah dengan lubang pengeluaran pipa penghantar

h. Tinggi vertikal antara permukaan air dalam tangki pemasukan dengan lubang katup limbah

W1. Debit air yang terbuang melalui katup limbah

W2. Debit Pompa.

Gambar 3 : Instalasi pompa hidram"dan cara kerjanya.

Jika aliran dalam pipa yang tidak elastic dihentikan tiba-tiba, maka secara teori akan didapat tekanan yang secara formulasi sebagai berikut :

$\mathrm{D} H=\mathrm{V} * \mathrm{C} / \mathrm{g}$

Keterangan :

$\mathrm{DH} \quad$ : Tekanan yang muncul [m]

$\mathrm{V} \quad$ : Kecepatan aliran dalam pipa $[\mathrm{m} / \mathrm{s}]$
C : Kecepatan gelombang akustik [m/s]

g : Percepatan gravitasi $\left(9.81 \mathrm{~m} / \mathrm{s}^{2}\right)$. David and Edward (1985) kecepatan gelombang akustik dalam fluida adalah sebagai berikut :

$C=\left(E_{v} / r h o\right)^{1 / 2}$

Keterangan :

$\mathrm{E}_{\mathrm{v}} \quad$ : Elastisitas modulus, yang dicerminkan oleh kompresibilitas fluida. Perubahan rasio setiap setiap penambahan tekanan yang berhubungan dengan perubahan volume. Untuk air, nilainya $E_{v}=2.07 \times 109 \mathrm{~N} / \mathrm{m}^{2}$, sehingga nilai kecepatan C menjadi 1440 $\mathrm{m} / \mathrm{s}$.

rho : Densitas $\left[\mathrm{kg} / \mathrm{m}^{3}\right]$

Persamaan 1 mewakili kemungkinan kenaikan maksimum. Kenaikan aktual akan lebih rendah dari pada yang dihitung oleh formula 1. Semua pipa mempunyai elastisitas dan tidak mungkin aliran tiba-tiba berhenti di dalam pipa. Head $(H)$ yang muncul akan mendorong aliran melalui katub limbah. Adapun formulasinya digambarkan sebagai berikut :

$H-f^{*}(L / D) * V^{2} /(2 * g)-\Sigma\left(K^{*}\left(V^{2}\right) /(2\right.$ * $\left.g)\right)=$ $(\mathrm{L} / \mathrm{g}){ }^{*} \mathrm{dV} / \mathrm{dt}$

Keterangan :

$\mathrm{H}$ : Head Supply [m] $f^{*}(\mathrm{~L} / \mathrm{D}){ }^{*} \mathrm{~V}^{2} /\left(2{ }^{*} \mathrm{~g}\right)$ adalah kehilangan tekanan dalam pipa [m]

f : Faktor gesekan (Darcy-Weibach Formula) [-]

$\mathrm{K}$ : Faktor kontraksi [-]

$\mathrm{L} \quad$ : Panjang pipa penghantar [m]

D : Diameter pipa penghantar [m]

V : Kecepatan Aliran Dalam Pipa [m/detik]

t : Waktu [detik]

$\Sigma\left(\mathrm{K}^{*}\left(\mathrm{~V}^{2}\right) /\left(2{ }^{*} \mathrm{~g}\right)\right)$

: adalah jumlah kehilangan tekanan (head) minor $[\mathrm{m}]$

Nilai $\mathrm{K}$ dan $\mathrm{f}$ dapat ditemukan pada buku standar mekanika fluida. Biasanya aliran ini akan cukup mempercepat untuk mulai menutup klep limbah. Penutupan terjadi jika tekanan dalam air sama dengan berat klep limbah. Besarnya tenaga pergeseran pada klep limbah diatur oleh formula sebagai berikut :

$F_{d}=C_{d}{ }^{*} A_{V}{ }^{*}$ rhow $_{w}^{*} V^{2} /(2 * g)$

Keterangan :

$\mathrm{Fd}$ : Tenaga penggeser (drag force) klep limbah[N]

$A_{v}$ : Luas penampang klep limbah $\left[\mathrm{m}^{2}\right]$

rhow densitas air $=1000 \mathrm{~kg} / \mathrm{m}^{3}$

$\mathrm{C}_{\mathrm{d}}$ : Koefisien geser klep limbah [-] 
$\mathrm{C}_{d}$ tergantung pada bilangan Reynolds pada aliran dan bentuk dari obyeknya. Untuk bentuk piringan melingkar $C_{d}=1.12$.

Dengan mengatur berat katup limbah dan jarak antara lubang katup dengan katup limbah, diharapkan hidram dapat memompa air sebanyak mungkin dan biasanya terjadi bila siklus berlangsung kira-kira 75 kali tiap menit. Pada Gambar 4, diperlihatkan dengan secara sangat sederhana bentuk ideal dari tekanan dan kecepatan aliran pada ujung pipa pemasukan dan kedudukan katup limbah selama satu siklus kerja hidram.
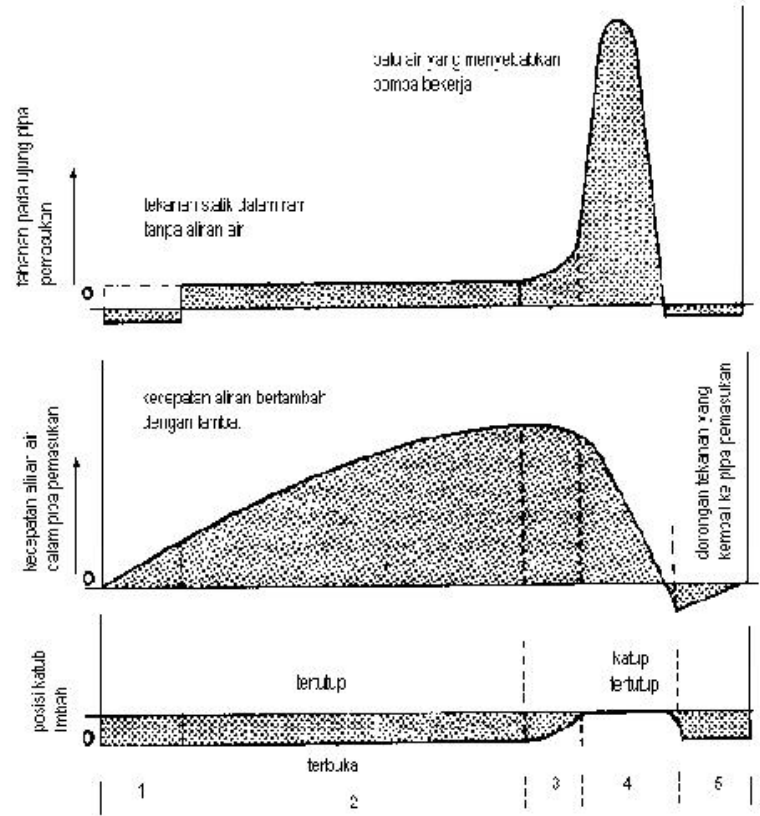

Gambar 4 : Diagram satu siklus kerja hidram

Keterangan Gambar 4, diagram siklus yang menunjukkan satu siklus denyut tekanan dari hidram.

- Periode 1. Akhir siklus yang sebelumnya, kecepatan air melalui ram mulai bertambah, air melalui katup limbah yang sedang terbuka, timbul tekanan negatif yang kecil dalam hidram.

- Periode 2. Aliran bertambah sampai maksimum melalui katup limbah yang terbuka dan tekanan dalam pipa pemasukan juga bertambah secara bertahap.

- Periode 3. Katup limbah mulai menutup dengan demikian menyebabkan naiknya tekanan dalam hidram. Kecepatan aliran dalam pipa pemasukkan telah mencapai maksimum.

- Periode 4. Katup limbah tertutup, menyebabkan terjadinya palu air (water hammer) yang mendorong air melalui katup pengantar. Kecepatan aliran pipa pemasukan berkurang dengan cepat.

- Periode 5. Denyut tekanan terpukul ke dalam pipa pemasukan, menyebabkan timbulnya hisapan kecil dalam hidram. Katup limbah terbuka karena hisapan tersebut dan juga karena beratnya sendiri. Air mulai mengalir lagi melalui katup limbah dan siklus hidram terulang lagi.

\subsection{Karakteristis}

Pompa hidram mempunyai karak-teristik yang berbeda-beda tergantung pada ketinggian air masuk, diameter pipa yang digunakan, berat pemberat pada klep limbah, diameter pipa penghantar. Pada contoh kasus dengan jumlah air yang masuk konstan, Pada ketinggian air $(\mathrm{Hd})=$ $3 \mathrm{~m}, 3 \mathrm{~m}, 5 \mathrm{~m}$ dan $6 \mathrm{~m}$, berat klep pemberat $2,2 \mathrm{~kg}$ dan diameter pipa penghantar $11 / 4$ " hubungan stroke dan efisiensi dapat dilihat pada Gambar 5. Efisiensi tertinggi (diatas $80 \%$ ) terjadi pada $\mathrm{Hd}=$ $3 \mathrm{~m}$, stroke 5 .

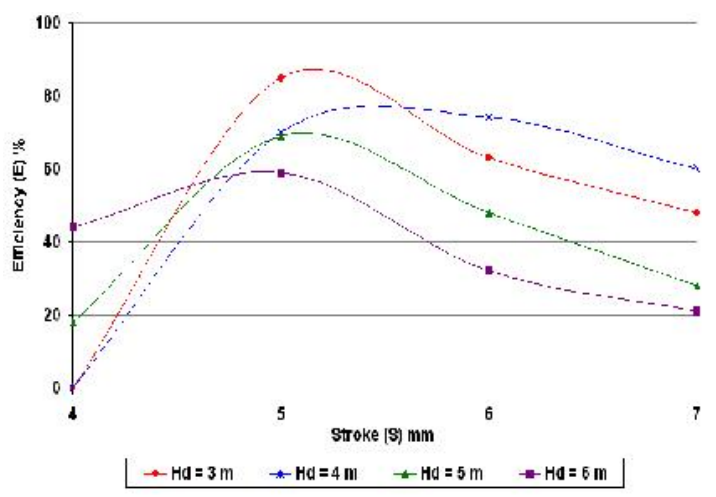

Gambar 5: Hubungan Stroke dan Effisiensi

Air yang didapat akan semakin besar (efisien) jika perbandingan tinggi air masuk dan keluar (head rasio) rendah. Pada kondisi ratio ketinggian air masuk dan keluar 0,5, maka efisiensi aliran dapat mencapai $50-60 \%$. Efisiensi akan menurun sampai dengan $20 \%$, jika head rasio mencapai 2 (Gambar 6). Dalam aplikasi pemakaian, tentu perlu penyesuaian dengan kondisi yang sesungguhnya, oleh karena itu dengan kondisi ukuran pipa yang sama, maka debit air yang didapat dan pengaturan ketinggian dapat dilihat pada Gambar 7.

Jumlah pukulan persatuan waktu atau denyut tekanan atau stroke (s) mempunyai hubungan erat dengan efisiensi kinerja (Gambar 8). Pengaturan denyut tekanan tergantung pada berat pemberat pada katub limbah (waste valve), yang disesuaikan dengan tinggi air dan diameter pipa yang digunakan. Pada desain untuk aplikasi sebaiknya pemberat dibuat tidak tetap, disesuaikan dengan 
kebutuhan, sehingga pengaturan stroke dapat optimal. Fungsi pemberat dapat digantikan dengan pegas, namun kelemahannya pegas dapat melemah kelenturannya.

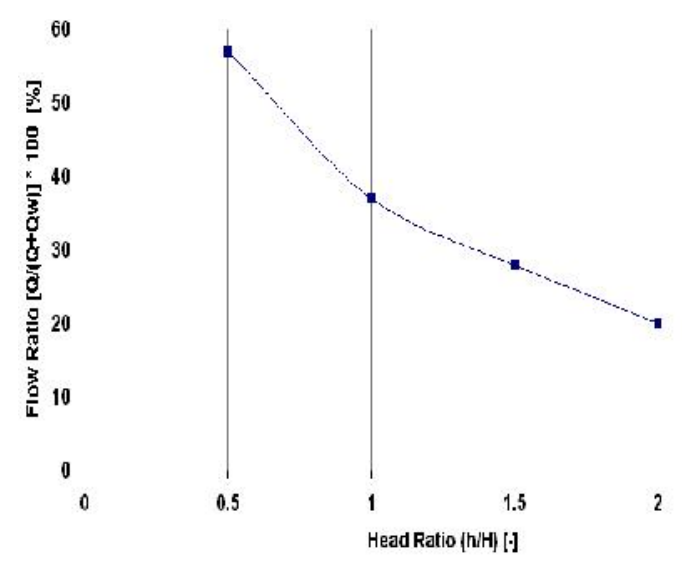

Gambar 6: Hubungan Ratio Ketinggian dan Rasio Aliran.

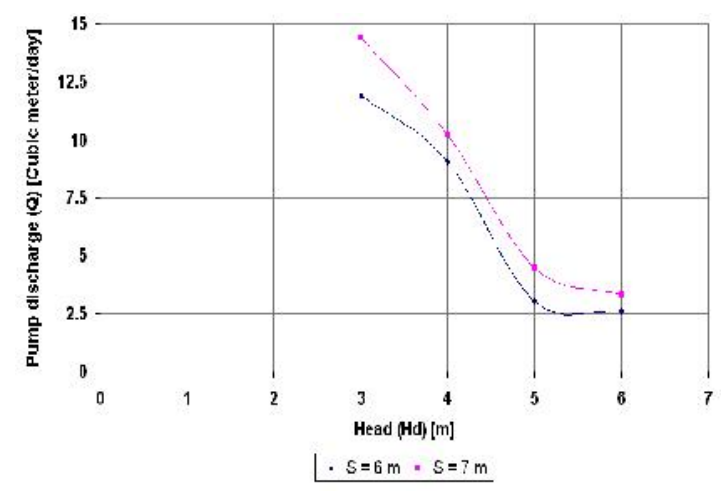

Gambar 7 : Hubungan Ketinggian air (Head) dan debit pemompaan (Pump Discharge).

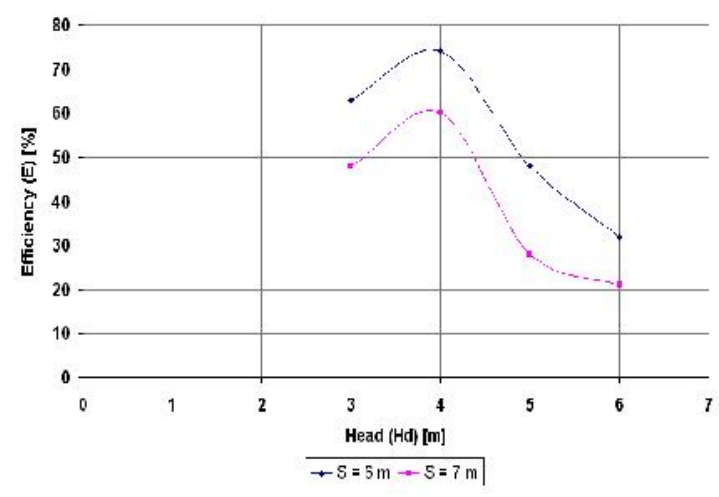

Gambar 8: Hubungan Ketinggian Jatuh Air (Head) dan Effisiensi pada kondisi denyut tekanan (S) 6 dan 7.

\section{RANCANGAN KONSTRUKSI.}

Hidram komersil yang ada telah dirancang kembali dan diperbaiki berdasarkan pengalaman yang diperoleh di lapangan sampai ram dapat bekerja baik pada semua keadaan dengan pemeliharaan yang minimum. Hidram dibuat dari bahan besi cor yang kuat, sehingga terdapat ram yang dapat bekerja sampai 100 tahun. Di Jawa Barat ada beberapa pompa hidraulik, yang masih beroperasi, dan dibuat sebelum perang dunia kedua, misalnya dekat Pelabuhan Ratu.

Hidram yang berasal dari ITDG, London dan yang dibicarakan di sini adalah ram yang dibuat dari pipa-pipa besi cor dan sambungan pipa yang banyak terdapat di pasaran bebas dengan ukuran 2 inchi. Penentuan ukuran ram pada umumnya ditentukan berdasarkan ukuran diameter dalam dari pipa pemasukan . Beberapa pabrik pembuat hidram menentukan ukuran ram produksinya berdasarkan ykuran diameter dalam dari pipa pemasukan tersebut (Tabel 1).

Tabel 1. Ukuran hidram buatan PTP-ITB, Bandung dengan Modifikasi Design I.T.D.G., London

\begin{tabular}{|c|c|c|}
\hline Type & $\begin{array}{c}\text { Garis Tengah Dalam } \\
\text { Pipa Pemasukan } \\
\text { (inchi) }\end{array}$ & $\begin{array}{c}\text { Garis Tengah Dalam } \\
\text { Pipa Pengeluaran } \\
\text { (inchi) }\end{array}$ \\
\hline 1 & 1,5 & 0,75 \\
\hline 2 & 2,0 & 1,0 \\
\hline 3 & 3,0 & 1,5 \\
\hline 4 & 4,0 & 2,0 \\
\hline 5 & 5,0 & 3,0 \\
\hline
\end{tabular}

\subsection{Katup limbah (waste valve)}

Katup limbah merupakan salah satu bagian penting dari hidram, dan harus dirancang dengan baik sehingga berat dan gerakannya dapat disesuaikan. Katup limbah dengan tegangan yang berat dan jarak antara lubang katup dengan karet katup cukup jauh, memungkinkan kecepatan aliran air dalam pipa pemasukan lebih besar, sehingga pada saat katup limbah menutup, terjadi energi tekanan yang besar dan menimbulkan efek palu air (water hammer effect).

Katup limbah yang ringan dan gerakanya pendek akan memberikan pukulan atau denyutan yang lebih cepat dan menyebabkan hasil pemompaan lebih besar pada tingggi pemompaan rendah. Penelitian mengenai bentuk dari katup limbah masih kurang, tetapi pada saat ini jenis katup kerdam sederhana kelihatannya bekerja cukup baik. Beberapa model hidram komersil telah menggunakan jenis katup kerdam yang dilengkapi dengan per tetapi belum diketahui apakah hal tersebut meningkatkan efisiensi ram, yang jelas jenis ini menghindari pemakaian "sliding bearing" 
yang harus diganti bila aus. Komponen dari suatu katup limbah dapat dilihat pada Gambar 9.

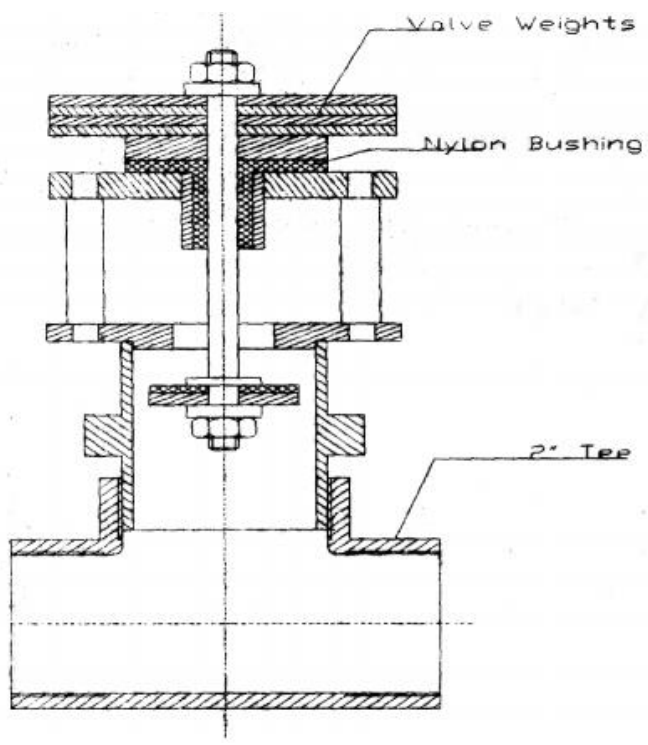

Gambar 9 : Katup Limbah dan komponen yang menyusunnya.

\subsection{Katup Pengantar (Delivery Valve)}

Katup pengantar harus mempunyai lubang yang besar, sehingga memungkinkan air yang dipompa memasuki ruang udara tanpa hambatan pada aliran. Katup ini dapat dibuat dengan bentuk yang sederhana yang dinamakan katup searah (non return). Katup ini dibuat dari karet kaku dan bekerja seperti pada katup kerdam (Gambar 10).

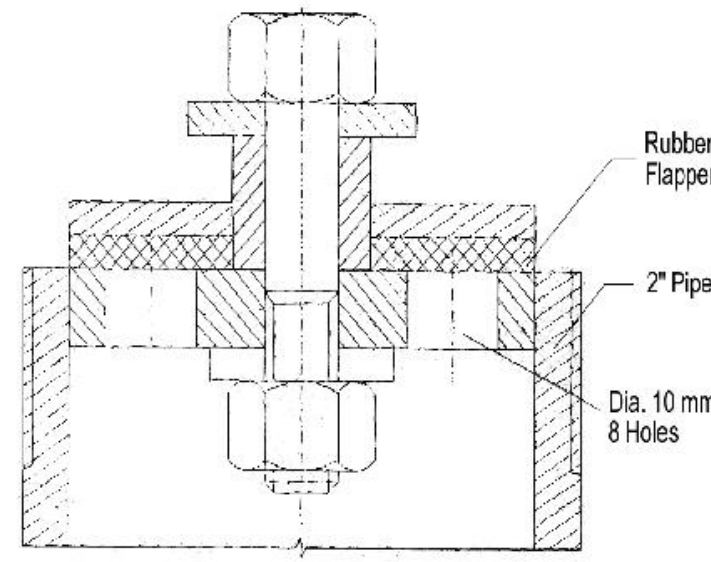
Valve).

Gambar 10 : katup searah (Non-Return

\subsection{Ruang Udara (Air Chamber)}

Ruang udara harus dibuat sebesar mungkin untuk memampatkan udara dan menahan tegangan tekanan (pressure pulse) dari siklus ram, memungkinkan aliran air secara tetap melalui pipa pengantar dan kehilangan tenaga karena gesekan diperkecil. Jika ruang udara penuh air, ram akan bergetar keras dan dapat mengakibatkan ruang udara pecah. Jika hal ini terjadi ram harus dihentikan dengan segera.

Beberapa ahli menyarankan bahwa volume ruang udara harus sama dengan volume air dalam pipa pengantar. Pada pipa pengantar yang panjang hal ini akan membutuhkan ruang udara yang terlalu besar dan untuk itu sebaiknya dirancang ruang udara dengan ukuran yang kecil.

\subsection{Katup Udara (Air Valve)}

Udara yang tersimpan dalam ruang udara diisap perlahan-lahan oleh turbulensi air yang masuk melalui katup pengantar dan hilang ke dalam pipa pengantar. Udara ini harus diganti harus diganti dengan udara baru melalui katup udara. Katup udara harus disesuaikan, sehingga mengeluarkan semprot-an air yang kecil setiap terjadinya denyutan kompresi.

Jika katup udara terbuka terlalu besar, maka ruang udara terisi dengan udara dan ram akan memompa udara. Jika katup kurang terbuka, sehingga tidak memungkinkan masuknya udara yang cukup banyak maka ram akan bergetar. Keadaan ini harus diperbaiki dengan memperhatikan besar lubang udara.

\subsection{Pipa Pengantar (Delivery Pipe)}

Hidram dapat memompa air pada ketinggian yang cukup tinggi. Dengan menggunakan pipa pengantar yang panjang akan menyebabkan ram harus mengatasi gesekan antara air dengan dinding pipa. Pipa pengantar dapat dibuat dari bahan apapun, termasuk pipa plastik tetapi dengan syarat bahan tersebut dapat menahan tekanan air.

\section{RANCANGAN PENDAHULUAN}

Survei untuk sebuah hidram harus dilakukan dengan mempertimbangkan rancangannya. Sebelum sebuah rancangan dapat dibuat, beberapa hal perlu diketahui dan diperkirakan dengan cermat, antara lain :

1). Tinggi jatuh vertikal dari sumber air sampai lokasi rencana pompa hidram akan diletakkan.

2). Daya angkat vertikal dari pompa sampai tempat penampungan. 3). Jumlah air yang tersedia untuk memberi tenaga pada pompa (pemasukan aliran sumber (Q). 4). Jumlah minimum air yang diperlukan setiap hari. 5). Panjang pipa pemasukan dari sumber air ke pompa dan 6).Panjang pipa pengeluaran dari pompa ke tempat penampungan. 7). Jarak dari pompa hidram sampai lokasi air diperlukan dan perbedaan ketinggian penting untuk diketahui dari awal. 
Penelitian calon lokasi sebaiknya diamati cukup detail dan sebaiknya bertanya pada penduduk desa setempat, tentang kualitas air dan kemungkinan perubahan jumlah air pada perubahan musim, serta masalah pengendapan atau sampah. Perhatikan 1). Tempat yang mempunyai potensi untuk banjir, tanah longsor atau erosi, 2). Lokasi rumah pompa, 3). Arah aliran air yang tak terpakai dari pompa akan dialirkan. Dan 4). Posisi pipa ditanam atau cukup dipermukaan.

Selanjutnya hitung ukuran dasar ini dengan menggunakan rumus :

$Q$ (output)/hari =

( tinggi jatuh vertikal $x$ aliran sumber (L/dtk $x$ $\left.0,6^{*}\right)$ ) / Daya angkat vertikal

Kita dapat memperkirakan jumlah air yang dikeluarkan per hari. Bandingkanlah bilangan ini dengan jumlah air yang dibutuhkan perhari (45 liter per orang per hari dianggap mencukupi untuk pemakaian setempat di desa pegunungan di Indonesia). Jika pengeluaran pompa dihitung terlalu kecil, maka penggunaan sebuah hidram tidaklah menguntungkan. Jika air tersedia dengan cukup, maka hitunglah kebutuhan air desa yang bersangkutan dengan memperhitungkan pengguna-an air setempat, pemakaian air oleh ternak, dan kalaupun ada pemakaian air untuk Irigasi pada skala yang kecil untuk pohonpohon buah dan kebun sayuran.

Jadikanlah angka yang dihasilkan tersebut jumlah air yang diinginkan dan kemudian hitunglah aliran pemasukan yang dibutuhkan dengan rumus sebagai berikut :

$\mathrm{Q}($ alliran pemasukan $=$

( daya angkat vertikal $\times Q$ (pengeluaran ) / Tinggi jatuh vertikal $X 0,6$

Dengan memperbesar tinggi jatuh vertikal, pengeluaran akan bertambah besar secara proporsional. Salah satu cara untuk memperbesar tinggi jatuh vertikal jika terlalu pendek, adalah dengan cara mengalirkan air dari sumber melalui pipa (atau saluran) ke sebuah tempat yang lebih rendah dari pada perbedaan ketinggian dengan pompa lebih besar. Untuk pipa pemasukan pertama dapat dipergunakan pipa HDP (High Densitiy Polythylene), tetapi pipa yang berhubungan dengan pompa haruslah pipa GI (Galvanized Iron = besi yang digalvanisir) atau pipa baja. Sambungan kedua pipa itu dapat merupakan pipa berdiri (stand pipe) yang terbuka, jika pipa HDP yang bersangkutan lebih besar satu ukuran dari pipa pemasukan, atau dapat dibuat sebuah tangki kecil yang mempunyai pipa pemasukan, pengeluaran, pembuangan dan pelimpah.

Tangki perantara ini sangat berguna khususnya jika air mengandung banyak bahan endapan. Kegunaan sebuah pipa berdiri yang terbuka atau sebuah tangki pelimpahan adalah untuk menjamin bahwa sama sekali tidak terdapat udara dalam pipa pemasukan. Penggunaan pipa berdiri yang terbuka adalah terutama untuk instalasi-instalasi di mana tangki pemasukan dan lokasi hidram dibatasi oleh topografi disekitarnya, yang dapat mencegah dibuatnya pipa pemasukan yang lurus atau diperlukannya pipa pemasukan yang terlalu panjang atau tidak cukup curam. Pada penggunaan pipa berdiri yang terbuka panjang dan sudut pipanya pemasukan ditentukan oleh lokasi pipa berdiri tersebut.

Tangki pemasukan akan bervariasi sesuai dengan tempatnya, tetapi terdapat perbedaanperbedaan dasar mennurut sifat sumber air yang bersangkutan. Mata air, sungai-sungai, saluransaluran, sistem air gravitasi yang berpipa, dan sumber-sumber air artesis masing-masing memiliki tuntutannya sendiri. Tekhnik-tekhnik dan disain tangki pemasukan dan cara konstruksinya dapat ditemukan dalam buku-buku lain, namun beberapa perinsip dasar harus diingat. Jika sumber air akan dipakai untuk air minum maka pencemaran harus dihindarkan. Disain sumber saluran dan sungai harus memperhitungkan masalah pengairan, pusaran air dan erosi. Karena air umumnya mengandung bahan endapan sebaiknya tangki perantara ini mempunyai saluran pembuangan, hal ini juga memudahkan pemeliharaanya.

\section{PENGGUNAAN HIDRAM DI LAPANGAN}

\subsection{Ukuran Jumlah Air}

Ukuran Hydraulik Ram ditentukan oleh pengeluaran yang dikehendaki, atau dibatasi oleh jumlah air yang tersedia untuk menggerakkan pompa. Perkiraan untuk jumlah air yang maksimum dan minimum yang diperlukan untuk menggerakkan pompa, diberikan di bawah ini (Tabel 2). Hargaharga ini sangat bervariasi untuk pompa yang satu dan pompa yang lain, tergantung dari sifat katup limbahnya.

Jika kita membuat pipa sendiri, kita dapat menentukan jumlah maksimum air dengan memasang mur cadangan pada katup limbah atau perkaitan katup limbah dengan diameter lebih besar atau lebih kecil. 
Tabel 2. Jumlah minimum dan maksimum dan minimum kebutuhan air untuk berbagai ukuran hidram (Silver, 1977)

\begin{tabular}{|c|c|c|c|}
\hline $\begin{array}{c}\text { Badan } \\
\text { (Inci) }\end{array}$ & $\begin{array}{c}\text { Pompa } \\
\text { Milimeter }\end{array}$ & $\begin{array}{c}\text { Pemasukan } \\
\text { Minimum } \\
\text { Ltr/mnt }\end{array}$ & $\begin{array}{c}\text { Pemasukan } \\
\text { Maksimum } \\
\text { Ltr/mnt }\end{array}$ \\
\hline 1 & $(25)$ & $(7,6)$ & $(37,9)$ \\
\hline 1,5 & $(37)$ & $(17,1)$ & $(56,8)$ \\
\hline 2 & $(51)$ & $(30,3)$ & $(94,6)$ \\
\hline 2,5 & $(63,5)$ & $(56,8)$ & $(151,4)$ \\
\hline 3 & $(76)$ & $(94,6)$ & $(265)$ \\
\hline 4 & $(102)$ & $(151,4)$ & $(378,5)$ \\
\hline
\end{tabular}

\subsection{Pipa Pemasukan.}

Pipa pemasukan merupakan pertimbangan yang penting dalam desain keseluruhan. Setiap pembuat hidram pada taraf komersil mempunyai cara yang berbeda untuk menghitung diameter pipa pemasukan dan panjangnya, dan dalam kebanyakan hal dua cara yang berbeda akan menghasilkan jawaban yang berbeda. Untungnya pipa pemasukan akan memberikan hasil yang memuaskan dalam batas-batas diameter dan panjang yang luas.

Setelah memperkirakan tempat tangki pemasukan, saluran pemasukan dan tempat pemasangan pompa yang memberikan tinggi jatuh vertikal dan aliran yang maksimal, Hitunglah diameter pipa pemasukan dengan menggunakan tabel1 yang memberikan perkiraan kasar tentang kapasitas bermacammacam ukuran hydram. Pompa-pompa komersil dengan ukuran yang sama mempunyai kapasitas yang berbeda seperti juga pompa-pompa yang digambarkan dalam buku ini, tergantung dari ukuran katup limbahnya masing-masing.

Pastikanlah untuk mempertimbangkan perubahan-perubahan musim karena alliran sumber mata air atau sungai sangat berubah daiam musim-musiim yang berbeda. Setelah memilih pompa yang berukuran sesuai, pillilah pipa pemasukan yang sesuai pula (jika tinggi jatuh vertikal kurang dari $4,8 \mathrm{~m})$. Jika tinggi jatuh vertikal lebih dari $4,8 \mathrm{~m}$ maka diperbolehkan untuk mempergunakan pipa pemasukan yang satu ukuran lebih kecil (artinya 0,5 inci dan lebih kecil) untuk pompa pompa yang berukuran 1,5 inci dan lebih besar dari itu terutama bila biaya pemasangan pompa harus ditekan serendah mungkin pilihlah panjang pipa pemasukan 6 kali tinggi jatuh untuk tinggi jatuh kurang dari 4,8 meter, untuk tinggi jatuh 4,8 m sampai 7,6m, 4 kali tinggi jatuh, dan untuk 7,6 m sampai $15 \mathrm{~m}, 3$ kali tinggi jatuh. Kadang-kadang lebih mudah uuntuk memillih panjang pipa yang sesuai dengan pipa yang terdapat di pasaran.

\subsection{Pipa Pengantar}

Biasanya dipakai untuk pipa pangantar, pipa dari pralon (PVC masukan). Sepotong pipa besi yang digalvanisir yang dipasang pada pompa sebelum saluran pengantar dapat memprkuat pompa, tetapi tidak mutlak perlu. Namun jika daya angkat vertikal melebihi kekuatan pipa pengantar tersebut haruslah pipa besi yang digalvanisir.

Tabel 3. Garis tengah pipa pengantar sesuai dengan kapasitas pompa per hari.

\begin{tabular}{|l|c|c|c|c|c|c|}
\hline $\begin{array}{l}\text { Literl } \\
\text { hari }\end{array}$ & 3000 & 9000 & 14000 & 23000 & 55000 & 90000 \\
\hline $\begin{array}{l}\varnothing \\
\text { inci }\end{array}$ & 0,5 & 0,75 & 1,0 & 1,25 & 1,5 & 2,0 \\
\hline $\begin{array}{l}\varnothing \\
\mathrm{mm}\end{array}$ & 20 & 25 & 32 & 40 & 50 & 63 \\
\hline
\end{tabular}

Jika beberapa hidram dipakai bersama-sama, harus dipergunakan pipa pemasukan yang terpisah, tetapi dapat dipasang pipa pengantar yang sama.

Daya angkat hidram diangkat vertikal minimum adalah kira-kira dua kali tinggi jatuh vertikal, dan daya angkat vertikal maksimum adalah kira-kira dua puluh kali tinggi jatuh vertikal. Jika pipa pengantar mempunyai bagian-bagian yang terletak di mana udara mungkin terkumpul, sebuah katup udara atau sejenisnya akan diperlukan

\section{KESIMPULAN}

1. Peningkatan bahan bakar fosil yang cukup signifikan berakibat meningkatnya biaya operasional dalam pengadaan air bersih, teknologi pompa hidram merupakan salah satu alternatif untuk pengadaan air bersih dan murah.

2. Dalam aplikasi pompa hidram perlu diperhatikan kapasitas dan ketinggian sumber air terhadap daerah pelayanan, tingkat kebutuhan air dan jarak daerah pelayanan.

3. Daya angkat hydram diangkat vertikal minimum adalah kira-kira dua kali tinggi jatuh vertikal, dan daya angkat vertikal maksimum adalah kira-kira dua puluh kali tinggi jatuh vertikal.

4. Pembuatan pompa hidram sangat sederhana dan bahan-bahannya dapat tersedia didalam negeri, walaupun tidak semua daerah sesuai untuk pemakaian teknologi ini.

\section{DAFTAR PUSTAKA}

1) Abiy Awoke Tessema, 2000, Hydraulic Ram Pump System Design And Application, Development and Technology Adaptation Center Basic Metals and Engineering Industries Agency, P.O. Box 1180, Addis Ababa, Ethiopia. 
2) Calvert N. G. 1967, Hydraulic Ram, THE ENGINEER,

3) David, J.P. and Edward, H.W., 1985, Schaum's Outline of Theory and Problems of Fluid Mechanics and Hydraulics, SI (Metric) Edition, McGrawHill Book Company, Singapore.

4) Dnadhar,M.M and Sharma, K.N, 1979, Water Power Engineering, Vikas Publishing House Pvt. Ltd. India.

5) IDRC, February 1986, Proceedings of a Workshop on Hydraulic Ram Pump (Hydram) Technology, held at Arusha, Tanzania, May 29-June 1, 1984, International Development Research Center (IDRC), IDRC-MR1O2e R.

6) ITB, 1979. Teknologi Pompa Hidraulik Ram - Buku Petunjuk untuk Membuat dan Pemasangan.
7) Jeffery, T. D. , 1992, Hydraulic Ram Pumps - A Guide to Ram Pumps Water Supply System, Intermediate Technology Publications.

8) Krol J., Automatic hydraulic Pump, PROC.I. MECH.E 1951, 164, p.103.

9) Molyneux F. 1960, The Hydraulic ram for Rival Water Supply, Fluid Handling, , p. 274.

10) Teferi Taye, 1998. Hydraulic Ram Pump, Journal of the Ethiopian Society of Mechanical Engineers, Vol. II, No. I, July 1998.

11) Watt S.B., 1975, Manual on the Hydraulic for Pumping Water, Intermediate technology publication, London.

12) Watt, S.B., 1982, Manual on a Hydraulic Ram for Pumping Water, Intermediate Technology Publication Ltd. London. 